\title{
THE ASSOCIATION BETWEEN MOTIVATION, SUPERVISION, AND WORK PERFORMANCE AMONG NURSES \\ IN DR. MOEWARDI HOSPITAL, SURAKARTA
}

\author{
Nureesa Doloh'), Didik Tamtomo², Endang Sutisna Sulaeman²) \\ 1)Masters Program on Public Health, Universitas Sebelas Maret \\ 2)Faculty of Medicine, Universitas Sebelas Maret
}

\begin{abstract}
Background: Motivation in work has been shown in earlier studies to determine employee performance. Motivation is a power that causes people to behave in a positive way that may result in better performance. However, empirical evidence on this association in hospital setting in Indonesia is lacking. The purpose of this study was to determine the association between motivation and work performance among nurses in hospital, after controlling for the effect of supervision.

Subjects and Method: This was a cross sectional study conducted at Dr. Moewardi Hospital, Surakarta, Central Java, from April to May 2018. A sample of 150 nurses was selected for this study by random sampling. The dependent variable was nurse performance. The independent variables were motivation and supervision. The data were collected by questionnaire and analyzed by a multiple linear regression.

Results: Nurse performance was associated with motivation $(\mathrm{OR}=3.24 ; 95 \% \mathrm{CI}=$ 1.45 to $7.21 ; \mathrm{p}=0.004)$ and supervision $(\mathrm{OR}=2.83 ; 95 \% \mathrm{CI}=1.31$ to $6.14 ; \mathrm{p}=$ 0.008). Nagelkerke $\mathrm{R}^{2}=22.0 \%$.

Conclusion: Nurse performance is associated with motivation, after controlling for the effect of supervision.
\end{abstract}

Keywords: motivation, supervision, nurse performance

\section{Correspondence:}

Nureesa Doloh. Masters Program on Public Health, Universitas Sebelas Maret. Jl. Ir. Sutami No. 36A, Surakarta 57126, Central Java.

Email: nursenuris2015@gmail.com. Mobile: +62895414785888. 